ELORE (ISSN 1456-3010), vol. $12-2 / 2005$.

Julkaisija: Suomen Kansantietouden Tutkijain Seura ry. Taitto: Jukka Talve ja Outi Fingerroos.

[http://cc.joensuu.fi/ /oristi/2_05/fin2_05.pdf]

\title{
PÄÄKIRJOITUS: VIERIVÄ KIVI EI KAI SAMMALOIDU
}

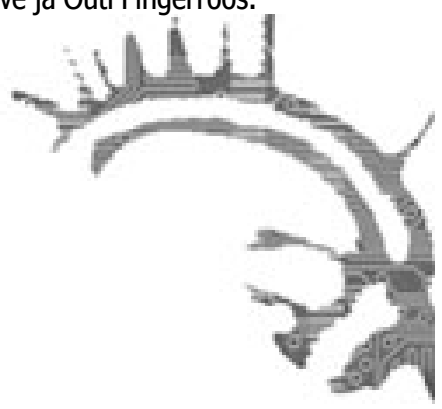

Outi Fingerroos

Vuosi 2005 sisältää muutoksia, tuulia ja monenlaisia jupinoita, sillä yliopisto on ottanut monia eri suuntiin vieviä askeleita. Siirtyminen kaksiportaiseen tutkintomalliin lienee askeleista pisin. Toivottavasti aikaa vaatinut panostus myös vie opiskelijoita ja tutkijoita eteenpäin Eurooppaan: raja-aitoja madaltaen ja kaikki yhdentymisen ideaalit toteuttaen. Itse olen viettänyt kuluneen syksyn Suomen Akatemian rahoittamana post doc -tutkijana Tartossa. Kaupungissa on paljon opiskelijoita ympäri Euroopan. Varsinkin Tartu ülikoolin eläinlääketiede vetää ylioppilaita, koska sisäänpääsy on huomattavasti vaikkapa Helsingin yliopistoa helpompaa. Tiedustelin tapaamiltani suomalaisopiskelijoilta, missä vaiheessa he siirtyvät Suomeen. He kertoivat jäävänsä, sillä Tarton opintoja ei hyväksilueta Suomessa. Jäinkin pohtimaan, mikä on "Tarton eläinlääkäreiden" markkina-arvo kuuden vuoden päästä Suomessa ja mikä onkaan sellainen tutkinnonuudistus, jossa siirtymät eivät ole mahdollisia.

Kaksiportaisen tutkinnon pitäisi mahdollistaa myös korkeakoululaitoksen sisäiset siirtymät. Toisin sanoen ammattikorkeakoulusta valmistunut opiskelija saa muodollisen pätevyyden siirtyä seuraavan syklin maisteriopintoihin myös yliopiston puolelle. Vastaavasti alemman korkeakoulututkinnon suorittanut voi halutessaan siirtyä ammattikorkeakouluun tekemään ylempää jatkotutkintoa. Tartossa keskustelin folkloristikollegani kanssa tästäkin aihepiiristä, sillä syyslukukauden alussa Viljandin kulttuuriakatemiasta siirtyi ensimmäinen opiskelija suorittamaan folkloristiikan maisteriopintoja Tartoon. Kollega pohti, onko opiskelijalla riittävästi eväitä pärjätä, sillä kulttuuriakatemian opetus on hyvin käytännönläheistä. Sama tilanne on Suomessa. Vasta aika näyttää, miten korkeakoululaitos sopeutuu uudistuksiin ja opiskelijat liikkuvat sen sisällä. Joka tapauksessa muutos houkuttaa ajattelemaan, että vielä jonain päivänä luovumme duaalimallisesta korkeakoululaitoksesta. Ainakaan opetusministeriön meneillään olevan tavoitekauden suunnitelmista ei voi löytää mitään sellaista, joka jarruttaisi yhdenmukaistavaa kehitystä. Ammattikorkeakouluihin esimerkiksi vakinaistettiin tänä syksynä joukko ylempiä jatkoopintolinjoja lyhyen kokeiluvaiheen jälkeen. 


\section{OUtI FingerRoOS}

Kolmas muutoksen tuuli on tietenkin UPJ. Protestilistoja allekirjoitettiin jo keväällä, ja laitoksilla on ehditty käydä esimiesten kanssa kehittäviä keskusteluja. Itse olen vakaasti sitä mieltä, että yliopistojen akateemisen vapauden vuosikymmenet ovat jo nyt historian mennyt lehti. Tehokkuus, tulosvastuu, arviointi ja huippuyksiköt ovat aikamme mantrat. Tämä kyynärpäitä kummasti kovettava ajattelutapa istuu mainiosti kokonaisuuteen, jossa myös perustutkinto-opiskelijoiden opintotuki ja väitöskirjaa tekevien apurahamahdollisuudet riippuvat nopeudesta. Humanistit saavat prosessissa mustelmia, sillä sinänsä ansiokas tutkimuksemme ei perinteisesti ole vakuuttaanut aivan kaikkia. Mieleen hiipii kuva vierivästä kivestä ja sammaleesta.

\section{VIELÄ KERRAN OPEN ACCESS}

Kyynikko on vain turhautunut optimisti. Eloressa ollaan syksyn jälkeen toiveikkaita, sillä rahoituskentän liikahdukset näyttäisivät lopulta tukevan suomalaisia open access -lehtiä. Opetusministeriö julkaisi muutama kuukausi sitten Avoimen tieteellisen julkaisutoiminnan työryhmän muistion (2005:8), jossa esitetään (s. 33), että Suomen Akatemia sekä korkeakoulut ja tutkimuslaitokset suosittaisivat tutkijoilleen tutkimusten julkaisemista avoimissa tiedelehdissä. Elore mainitaan opetusministeriön muistiossa yhtenä ensimmäisistä täysin avoimeen saatavuuteen perustuvista tiedejulkaisuista. Toimituskuntaa mairittelee myös Ilkka Niiniluodon näkemys, että tieteellisen julkaisutoiminnan ehdot ovat muuttumassa radikaalisti ja tieteellisten seurojen valtionavun jakoperiaatteet olisi uusittava.

Eloren vuosikymmenien aikana saavuttama asema poiki lokakuussa mielenkiintoisen pyynnön. FT Kalle Korhonen Helsingin yliopiston kirjastopalvelujen koordinointiyksiköstä pyysi minua päätoimittajana puhumaan HY:n julkaisuneuvottelukunnan 31.10. järjestämään Julkaisijan iltapäivään. Teemana oli se, miten open access:ia toteutetaan Suomessa käytännössä. Eloren päätoimittajana ker-

roin, millaisia kokemuksia meillä on avoimen saatavuuden julkaisutoiminnasta yli kymmenen vuoden ajalta ja miten lehtemme suhtautuu yliopistojen perustamiin avoimiin julkaisuarkistoihin. Vastaanotto oli hyvä ja tiedelehteämme kannustava; etenkin rahoituskentällä kohtaamiamme ongelmia pidettiin todellisina. Edellä mainittu on toki subjektiivinen arvioni, mutta tieteiden talon päätupa oli ainakin täynnä kuulijoita - Tieteellisten seurain valtuuskunnan, opetusministeriön ja Suomen akatemian delegaatiot muiden mukana.

Elore tuli oma-aloitteisesti esiin kuorestaan myös Tieteessä Tapahtun -lehden lokakuun numerossa (7/2005). Valoimme uskoa open access -lehtien parempaan huomeneen. Nyt, kun tieteellisten seurojen julkaisutukien jako siirtyy Suomen akatemiasta Tieteellisten seurain valtuuskunnan kontolle, on tilanteen muututtava. TSV:n täytyy olla se taho, joka kykenee reagoimaan open access -lehtien ahdinkoon. Eiköhän näin tapahdukin, ajallaan. 


\section{ELORE 2/2005}

Uusin Elore on sisältönsä puolesta muhkea kokonaisuus. Vuoden alussa päätimme, että syksyn numerot ovat jatkossa teemoista vapaita. Saimmekin syksyn numeroon useita tekstitarjouksia ilman rekrytointia, ja runsauden sarvesta johtuen emme voineet ottaa kaikkia artikkelitarjouksia vastaan. Kriteerimme on, että tarjotut tekstit keskustelevat folkloristiikan kysymyksistä kiinnostavasti ja ajankohtaisesti tai sijoittuvat muuten kulttuurien tutkimuksen keskiöön. Samaa ideaa toteutamme kirja-arvioissa, joita lehtemme julkaisee nykyisellään ehdottoman enimmäismäärän.

Artikkeleita tuoreessa numerossa on yhteensä kuusi kappaletta, enkä edes yritä rakentaa niiden välille punaista lankaa. Kaikki ne ovat itsenäisiä puheenvuoroja erilaisista tutkimuksen teemoista. Vuosi 2005 on ollut väitösten osalta jälleen runsas ja mielenkiintoinen. Tässä numerossa julkaisemme Johanna Uotisen, Pauliina Latvalan ja Lotte Tarkan lectiot. Kevään numeroon niitä tulee loppuvuoden osalta lisää. Lisäksi mukana on kuulumisia meiltä ja maailmalta. Tärkeä teksti on FT Katariina Sorvarin selvitys muuttuvan tekijänoikeuslain vaikutuksista.

Kiitän kaikkia kirjoittajia aktiivisuudesta ja toivon lukijoille inspiroivia hetkiä. Kevään 2006 teemanumeron aiheena on Oral History in Finland, Baltia and Russia. Syksyn 2006 numeron toimittaminen alkaa heti tarjousten ilmaannuttua tämä esitettäköön kutsuna!

\section{LÄHTEET}

Avoimen tieteellisen julkaisutoiminnan työryhmän muistio. Opetusministeriön työryhmämuistioita ja selvityksiä 2005:8 [online]. < http://www.minedu.fi/julkaisut/tiede/2005/tr08/tr08.pdf > [Viitattu 9.11.2005]

FINGERROOS, OUTI 2005: Tieteellinen julkaisutoiminta murroksessa. - Tieteessä tapabtun 22(7) [online]. < http://www.tieteessatapahtuu.fi/0705/Fingerroos.pdf $>$ [Viitattu 9.11.2005]

NIINILUOTO, ILKKA 2005: Tieteellinen julkaisutoiminta murroksessa. - Tieteessä tapahtun 22(4) [online]. < http://www.tieteessatapahtuu.fi/0405/ Niiniluoto.pdf $>$ [Viitattu 9.11.2005] 